\title{
Analysis and Design Ecommerce with User Centered Design (UCD) Method at PT. Multi Prima Mandiri Sukses
}

\author{
Singgih Tanu Putra ${ }^{1}, E d y^{2}$ \\ ${ }^{1}$ Buddhi Dharma University, Information System, Banten, Indonesia \\ ${ }^{2}$ Buddhi Dharma University, Software Engineering, Banten, Indonesia
}

\begin{tabular}{l}
\hline SUBMISSION TRACK \\
\hline Received: Aug 26, 2020 \\
Final Revision: Sept 19, 2020 \\
Available Online: Sept 29, 2020 \\
KEYWORD
\end{tabular}

Marketing, Website, Technology, Internet, $U C D$

CORRESPONDENCE

Email: singgihtanuputra@gmail.com

\section{INTRODUCTION}

The development of technology that is too advanced, beyond many people think, requires all parts of human activity to be able to adopt, adapt, utilize and produce something that is useful for the continuity of life. In the era of technological in the 20th century, the business process was driven by changes in overall system, neither directly or indirectly, technology had an impact on the trading system. Directly proportional to technological advances, especially the internet, at this time the coverage between buyers and sellers is very broad and is not limited to time and place, where all limitations of time, distance and place, as well as costs can be trimmed and easily overcome by the internet which is now

\begin{abstract}
A B S T R A C T
The development of technology moves so rapidly beyond human expectations in general, all eyes and minds are shocked by the sophistication of a technology that is packaged to represent various systems in the world, as well as the business world which is touched by technological developments and changes the way of doing business from the old model to be more sophisticated and efficient. PT. Multi Prima Mandiri Sukses is a company that sells laserjet toner ink and various laserjet printer rentals for office needs. The problem that occurs is in the sales department that so far sales are still carried out conventionally by ordering by telephone and sales records are still in the form of physical data where sales reach is not wide and sales data are easily to lost. To overcome this problem, an online sales platform was built in the form of e-commerce with the UML (Unified Modeling Language) approach and with the design of the UCD (User Centered Design) method, the programming language used was PHP with MySQL database. The results of this research are in the form of an available online sales system which includes purchases and sales reports with a user center as a reference for developing an e-commerce sales system.
\end{abstract}

increasingly being used. To be the heart of world telecommunications today. One of technology implementation in terms of increasing business, product sales and purchases is by using e-commerce. Ecommerce is a part of buying and selling transactions electronically through the internet. However, at this time, specifically in Indonesia, which is a developing country category with the largest number of islands in the world, it is recorded that according to data from the Indonesian Ministry of Cooperatives and Small and Medium Enterprises (Kemenkop UKM), in 2019 there were 3,79 million micro, small and medium enterprises. who are already using online platforms in marketing of their products. This number ranges from only 8 percent of 
the total Micro Small Medium Enterprise (MSME) players in Indonesia, which is around 59,2 million, of the total Indonesian population of more than 270 million in 2019 [1]. Internet use in the online business sector has grown rapidly. The total value of trade in goods and services in the world through ecommerce in Indonesia has been reached 146 trillion rupiahs per year of 2018, according to Bank Indonesia data [2]. The growth rate of commerce via the internet from year to year is recorded to have grown a significant double. This creates a natural sense of the sustainability of the trading business carried out by the business sector in surviving in the midst of the vastness of trade and the era of easy information exchange by demanding business owners to adapt. This writing is based on the author's work experience with Mr. Sunanto as the Business Owner of PT. Multi Prima Mandiri Sukses on September 25,2019 . The result of the conversation that there was a problem with the sales system at PT. Multi Prima Mandiri Sukses, namely that the company has not been able to reach retail sales for public consumers and has not been able to provide orders through the online system, where each sale is still conventionally accommodated which also often causes problems in sales reports. From here, to meet the challenges of adapting in business where similar competitors have made sales by utilizing E-commerce, the author wishes to analyze and design Ecommerce using the UCD (User Centered Design) method by focusing on usability, building an e-commerce system that suits your needs. users and user oriented in using e-commerce. Based on the background contained above, the writer intends to do research with the title "Analysis and Design of E-commerce with the UCD (User Centered Design) Method at PT. Multi Prima Mandiri Sukses "by using php programming language and using mysql as database.

\section{LITERATURES REVIEW Website}

Website is a system in which it deals with documents used as a medium for displaying information in the form of images, videos, text, sound and multimedia and others on the internet network [3]

\section{Hosting}

Hosting is a data storage (storage) website on the internet, which includes storage functions, bandwidth (speed) which is a capacity used to measure the number of website visitors and supported by database facilities [4].

\section{Internet}

Internet or interconnection networking is a global system of all computer networks that are connected to one another, the internet is a network consisting of billions of computers in it all over the world and involves different network topologies, they are connected to each other by cables data or wireless and TCP IP based system to exchange data [5].

\section{E-commerce}

E-commerce is a website that has been stored in media hosting that provides online buying and selling transactions or direct selling that utilizes internet technology, where the website is able to provide "get and deliver" [6].

\section{User Centered Design}

User Centered Design (UCD) is a design theory that places the user at the center based on the system development process. UCD has been supported by a variety of techniques, methods, tools, procedures, and processes that help approach a more usercentered interactive. Scoope at UCD is more than just making useful products. UCD is a new framework based on systems development. The term user-centered design is used to describe a design philosophy. The UCD concept is central, based on the system development process, \& the objectives or properties, context and environment of the 
whole system based on the user experience [7].

\section{FRAMEWORK}

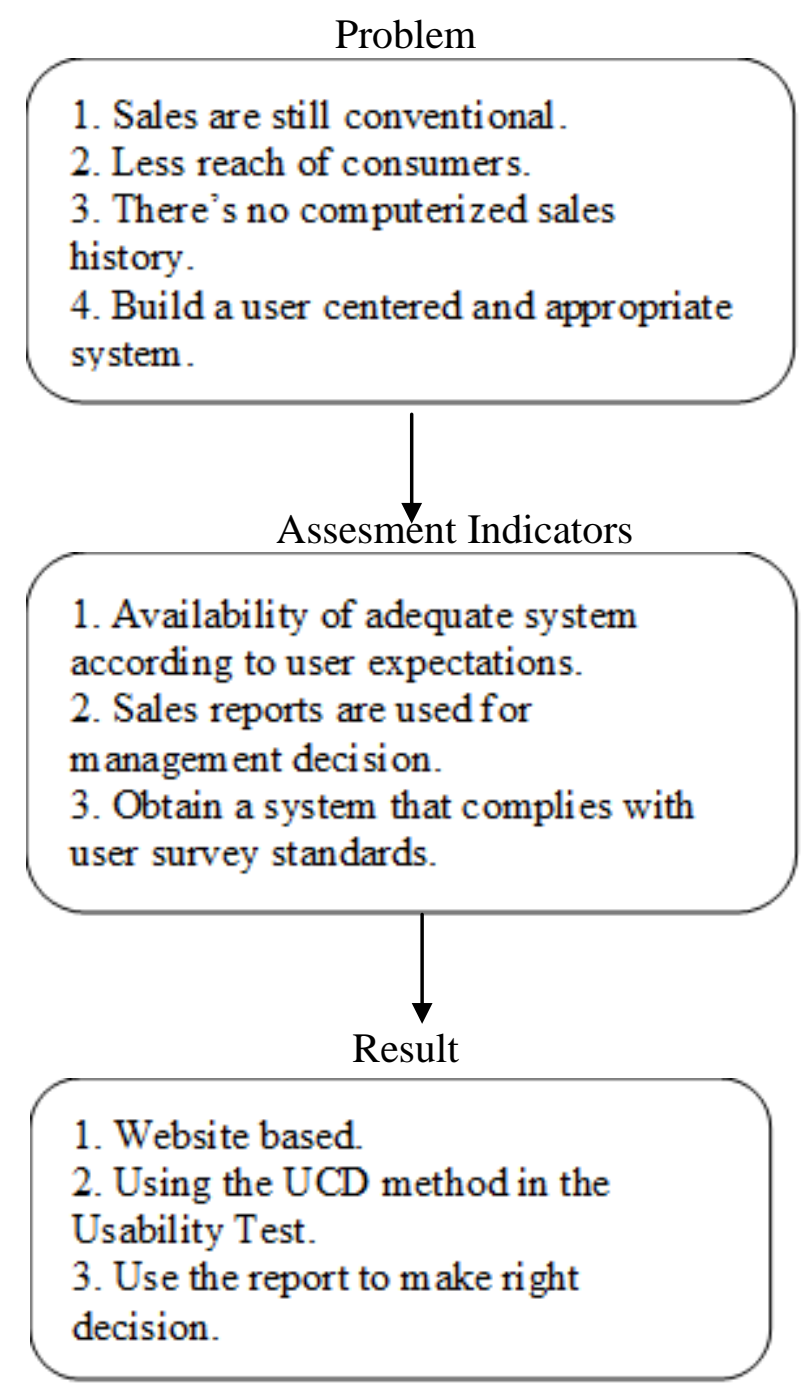

Figure 1. Framework

\section{METHODS}

\section{Use of the UCD Method}

The UCD processbased on the ISO 9241210: 2010 standard, there are 5 processes, that are [8]:

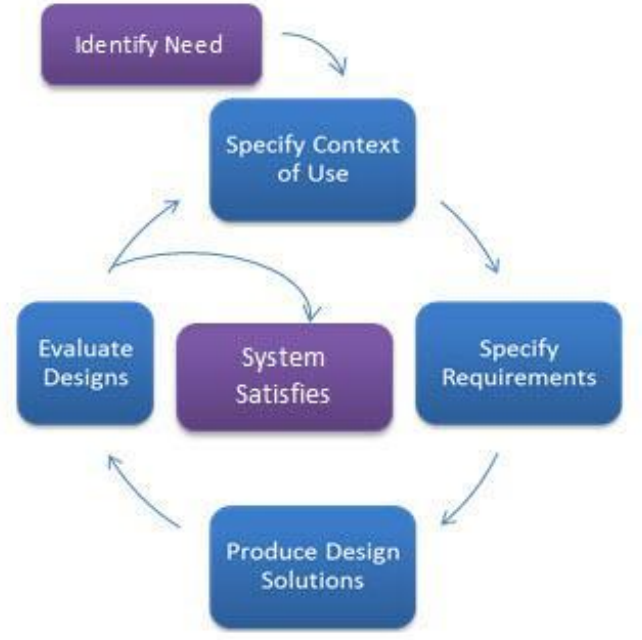

Figure 2. Process of UCD

a) UCD planning: At this stage a meeting is held with stake holders, stakeholders do executing interests by discussing the project budget, project schedule that will be carried out in connection with the development of this system.

b) Understand and define user context: To recognizing someone who will use result of a product system. This will identify what this product is used for and under what conditions they will use the product system.

c) Determine user needs: Introduction of user or organizational needs.

d) Solution: Build a design as a solution to solving problems of dynamic products.

e) Evaluation: evaluating the design carried out, whether user and organizational goals have been achieved.

\section{Usability}

Formally, usability can be defined as the level of ease of use of a product which includes the several following: 
Learnability is a criterion that measures the ease with which a site is learned and used, especially for first-time users viewing and browsing the site.

Efficiency is a criterion that measures the user's performance level when using the site.

Memorability is a qualitative criterion that can be seen through the ease with which users can reuse the product (site) after don't visit the site for while.

Errors are quantitative criteria on web usability, errors assessing the site through the number of errors made by users when performing a given scenario task.

Satisfaction is a qualitative measurement that it felt or shown by the user, when the system or site used is pleasant and easy to use, it will provide comfort to the user or also provide a sense of satisfaction when the user can complete the assigned task properly.

\section{Use Case Diagram of the Proposed System}

Use Case diagrams in the proposed system describe the process of the new proposed system, to make it easier to understand the proposed system, the business process is poured into the Use case diagram. The use case diagram is written in the form of actors who will use the system (user) who has access rights or system facilities that they can use, namely, the customer has the right to create an account, log in, make purchases online, the admin can manage web commerce accordingly sales requirements and managers have the right to access sales reports.

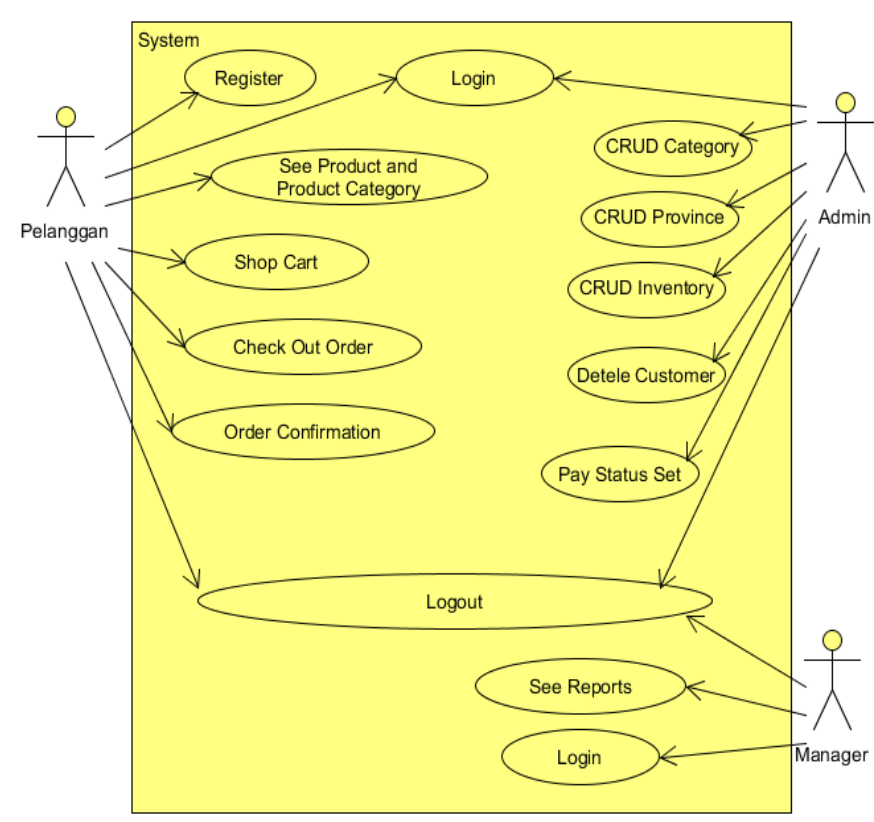

Figure 3. Use Case Diagram of the Proposed System

\section{Questionnaire Before Application}

To find out the user's needs in developing an information system, concrete data is needed by distributing questionnaires to respondents. This is an application of the UCD concept where the data is intended to determine the extent of user expectations in using an ecommerce system so that a user-centered system can be built.

\section{Post-Application Questionnaire}

After the system is built, the system usage value starts to be calculated by applying the Centered Design points with the data obtained from the distribution of questionnaires obtained from respondents. This is done to determine the value of the customer satisfaction score and user expectations of the system that has been built.

\section{RESULT}

\section{Questionnaire Calculations Before Application}

To obtain valid data and according to user needs, prior to the design process, clear information is needed which is carried out 
through the distribution of questionnaires to 25 respondents as follows:

Table 1. Quizoner Calculation Before Application

\begin{tabular}{|c|c|c|c|c|}
\hline No & Expectation & Yes & Neutral & No \\
\hline 1 & $\begin{array}{l}\text { Does the online purchasing website have to } \\
\text { provide complete information? }\end{array}$ & 18 & 7 & 0 \\
\hline 2 & $\begin{array}{l}\text { Should the product / device list be } \\
\text { categorized? }\end{array}$ & 21 & 3 & 1 \\
\hline 3 & $\begin{array}{l}\text { Should the product description be } \\
\text { accompanied by a product image? }\end{array}$ & 19 & 5 & 1 \\
\hline 4 & $\begin{array}{l}\text { In your opinion, do you need a product search } \\
\text { feature? }\end{array}$ & 24 & 1 & 0 \\
\hline 5 & $\begin{array}{l}\text { Should the ecommerce system be displayed } \\
\text { horizontally? }\end{array}$ & 10 & 2 & 13 \\
\hline 6 & $\begin{array}{l}\text { Should the ecommerce system be displayed in } \\
\text { a vertical form? }\end{array}$ & 14 & 8 & 3 \\
\hline 7 & $\begin{array}{l}\text { Is the color of the good application layout } \\
\text { with bright colors more attractive? }\end{array}$ & 17 & 7 & 1 \\
\hline 8 & Is the application better presented in Bahasa? & 14 & 10 & 1 \\
\hline 9 & $\begin{array}{l}\text { Should the login menu be placed in an easily } \\
\text { visible area? }\end{array}$ & 18 & 7 & 0 \\
\hline 10 & $\begin{array}{l}\text { Should the ad / promo on the application be } \\
\text { easy to see? }\end{array}$ & 17 & 3 & 5 \\
\hline \multicolumn{2}{|c|}{ Total (250 Answers) } & 172 & 53 & 25 \\
\hline
\end{tabular}

Based on the information on the results of the distribution of the questionnaires, it can be concluded that 25 respondents answered "Yes" to the indicator of the major user expectation questions, with the following percentages:

Yes $:(172 / 250) \times 100 \%=69 \%$

Neutral: $(53 / 250) \times 100 \%=21 \%$

No $:(25 / 250) \times 100 \%=10 \%$

\section{Percentage of Answers to the} Questionnaire

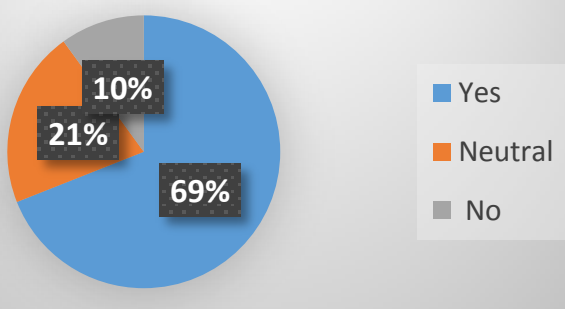

Figure 4. Percentage of Questionnaires Before Application

\section{Questionnaire \\ Calculation \\ after Application}

After the system is built, the system usability value starts to be calculated by applying the Centered Design points with the data obtained from the distribution of questionnaires obtained from 30 online and random respondents as follows:

Table 2. Questionnaire Calculation After Application

\begin{tabular}{|c|c|c|c|c|c|c|}
\hline No & Questions & STS & TS & $\mathbf{N}$ & $\mathrm{S}$ & SS \\
\hline \multicolumn{7}{|c|}{ A. Earnability 30 Persons $\times 3$ Questions $=90$ Answers } \\
\hline 1 & Can the text used on the website be read easily? & 0 & 0 & 4 & 15 & 11 \\
\hline 2 & Is the menu complete and easy to understand? & 0 & 0 & 5 & 15 & 10 \\
\hline 3 & $\begin{array}{l}\text { Can the user easily follow the manual procedure } \\
\text { given on the website? }\end{array}$ & 0 & 0 & 6 & 15 & 9 \\
\hline \multicolumn{7}{|c|}{ B. Effisiency 30 Persons $\times 3$ Questions $=90$ Answers } \\
\hline 4 & $\begin{array}{l}\text { Can the pages on the website be operated smoothly } \\
\text { on each page menu? }\end{array}$ & 0 & 1 & 8 & 7 & 14 \\
\hline 5 & Does the system contain unnecessary pages? & 3 & 10 & 11 & 6 & 0 \\
\hline 6 & Does the search field works? & 0 & 0 & 3 & 15 & 12 \\
\hline \multicolumn{7}{|c|}{ C. Memorability 30 Persons $\times 2$ Questions $=60$ Answers } \\
\hline 7 & Is the way to make a purchase memorable? & 0 & 0 & 6 & 16 & 8 \\
\hline 8 & Is the webiste viewing comfortable? & 1 & 1 & 6 & 15 & 7 \\
\hline \multicolumn{7}{|c|}{ D. Errors 30 Persons $\times 2$ Questions $=60$ Answers } \\
\hline 9 & Are there any bugs in the system? & 3 & 11 & 13 & 3 & 0 \\
\hline 10 & Is there a guide listed on the website? & 1 & 4 & 5 & 17 & 3 \\
\hline \multicolumn{7}{|c|}{ E. Satisfaction 30 Persons $\times 3$ Questions $=90$ Answers } \\
\hline 11 & Is information about the product conveyed well? & 0 & 0 & 7 & 13 & 10 \\
\hline 12 & $\begin{array}{l}\text { Is the image information on the website clearly } \\
\text { visible? }\end{array}$ & 0 & 0 & 5 & 17 & 8 \\
\hline 13 & $\begin{array}{l}\text { Do you intend to revisit the Multi Print website } \\
\text { commerce? }\end{array}$ & 0 & 0 & 9 & 12 & 9 \\
\hline & Total (390 Answers) & 8 & 27 & 88 & 166 & 101 \\
\hline
\end{tabular}

\section{Notes:}

STS : Strongly Disagree

TS : Disagree

$\mathrm{N}$ : Neutral

S : Agree

SS : Strongly Agree

From the information on the results of the questionnaire distribution above, the average value of Centered Design points can be calculated as follows: 
Table 3. Weight Value Table

\begin{tabular}{|c|c|c|c}
\hline No. & Answer & Code & Weight \\
\hline 1 & Strongly disagree & STS & 1 Point \\
\hline 2 & Disagree & TS & 2 Point \\
\hline 3 & Neutral & N & 3 Point \\
\hline 4 & Agree & S & 4 Point \\
\hline 5 & Strongly agree & SS & 5 Point \\
\hline
\end{tabular}

\section{- Earnability}

STS : 0

TS : 0

N $: \frac{15}{90} \times 100 \%=17 \% \times 3=\mathbf{0 . 5 1}$

S : $\frac{45}{90} \times 100 \%=50 \% \times 4=\mathbf{2}$

SS : $\frac{30}{90} \times 100 \%=33 \% \times 5=\mathbf{1 . 6 5}$

Total: 4.16 Points $=4.16 / 5 \times 100=$ 83.2\% of respondents decided that the system is easy to learn.

\section{- Efficiency}

STS : $\frac{3}{90} \times 100 \%=3 \% \times 1=\mathbf{0 . 0 3}$

TS : $\frac{11}{90} \times 100 \%=12 \% \times 2=\mathbf{0 . 2 4}$

N $:: \frac{22}{90} \times 100 \%=25 \% \times 3=\mathbf{0 . 7 5}$

S : $: \frac{28}{90} \times 100 \%=31 \% \times 4=\mathbf{1 . 2 4}$

SS $: \frac{26}{90} \times 100 \%=29 \% \times 5=\mathbf{1 . 4 5}$

Total: 3.71 Points $=3.71 / 5 \times 100=$ $\mathbf{7 4 . 2 \%}$ of respondents decided that the system has efficiency.

\section{- Memorability}

STS : $\frac{1}{60} \times 100 \%=2 \% \times 1=\mathbf{0 . 0 2}$

TS : $\frac{1}{60} \times 100 \%=2 \% \times 2=\mathbf{0 . 0 4}$

N $: \frac{12}{60} \times 100 \%=24 \% \times 3=\mathbf{0 . 7 2}$

S : $: \frac{21}{60} \times 100 \%=42 \% \times 4=\mathbf{1 . 6 8}$

SS $: \frac{15}{60} \times 100 \%=30 \% \times 5=\mathbf{1 . 5}$
Total: 3.96 Points $=3.96 / 5 \times 100=$ $\mathbf{7 9 . 2 \%}$ of respondents decided that the system is easy to remember.

\section{- Errors}

STS : $\frac{4}{60} \times 100 \%=7 \% \times 1=\mathbf{0 . 0 7}$

TS : $\frac{15}{60} \times 100 \%=25 \% \times 2=\mathbf{0 . 5}$

N : $\frac{18}{60} \times 100 \%=30 \% \times 3=\mathbf{0 . 9}$

S: : $\frac{20}{60} \times 100 \%=33 \% \times 4=\mathbf{1 . 3 2}$

SS : $\frac{3}{60} \times 100 \%=5 \% \times 5=\mathbf{0 . 2 5}$

Total: 3.04 Points $=3.04 / 5 \times 100=$ $\mathbf{6 0 . 8 \%}$ of respondents decided that the system can be accepted from errors.

\section{- Satisfaction}

STS : 0

TS : 0

$$
\begin{aligned}
& \text { N }: \frac{21}{90} \times 100 \%=23 \% \times 3=\mathbf{0 . 6 9} \\
& \text { S }: \frac{42}{90} \times 100 \%=47 \% \times 4=\mathbf{1 . 8 8} \\
& \text { SS }: \frac{27}{90} \times 100 \%=30 \% \times 5=\mathbf{1 . 5}
\end{aligned}
$$

Total: 4.07 Points $=4.07 / 5 \times 100=$ $\mathbf{8 1 . 4 \%}$ of respondents decided that the system can provide satisfaction.

\section{Discussion}

After knowing how the system works by paying attention to the implementation ofthe UCD method in it, the following will display the program display that was created. 


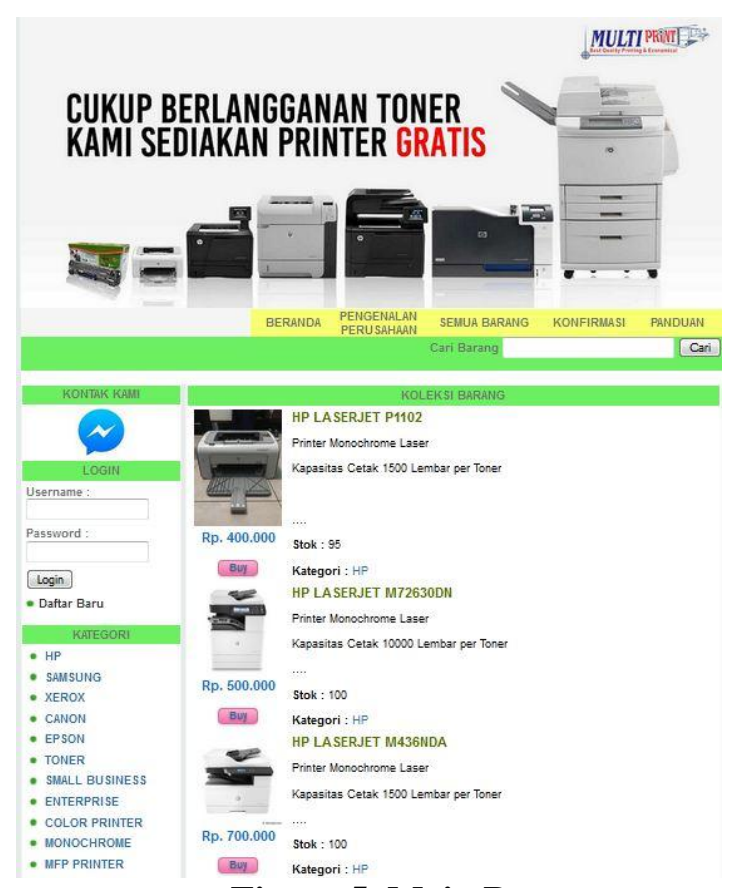

Figure 5. Main Page

Figure 5 above is the initial view and also the start page where users can access the ecommerce website.

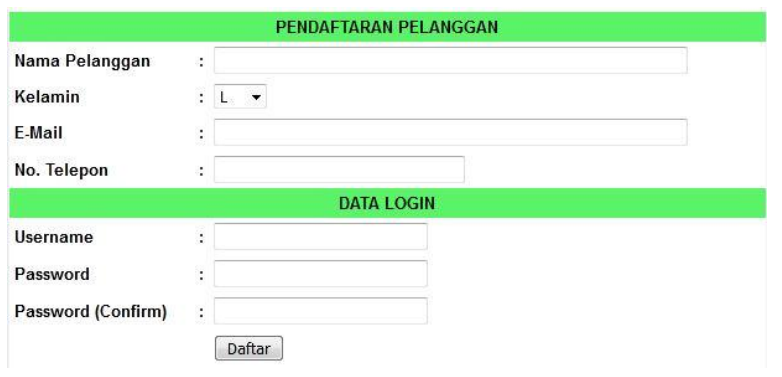

Figure 6. Registration Form

Figure 6 above is a registration form for new visitors who are used as an online shopping user account.

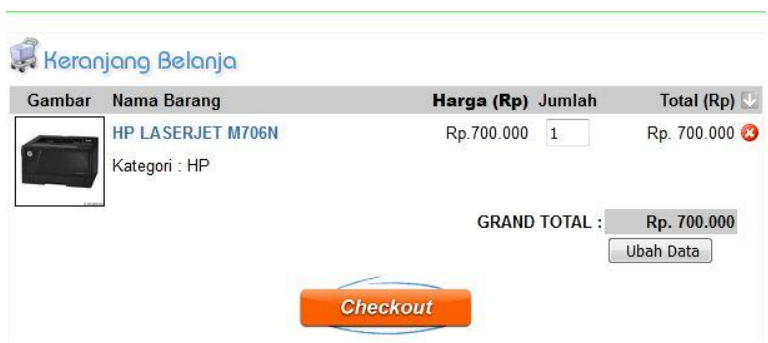

Figure 7. Shopping cart
Figure 7 is an image of a shopping cart, which is a place for visitors to buy orders before making a payment.

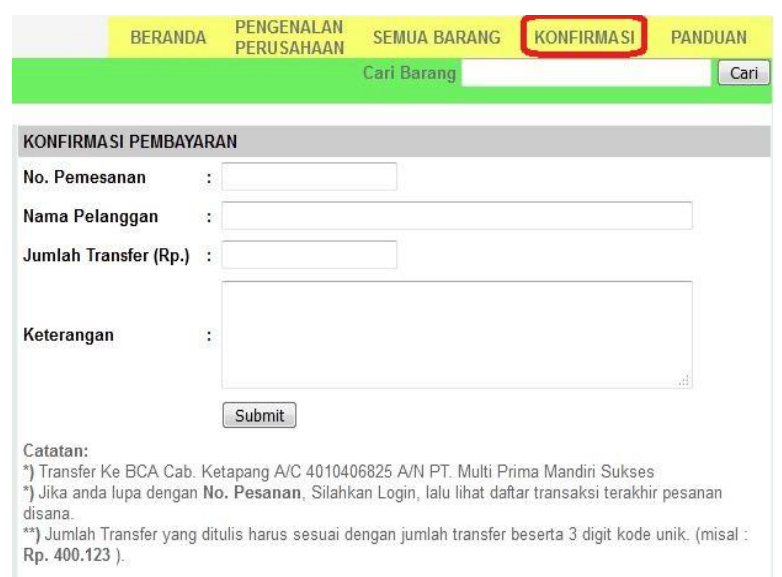

Figure 8. Order Confirmation

In this menu, order confirmation is done manually, where the buyer has transferred payment for goods and confirmed manually.

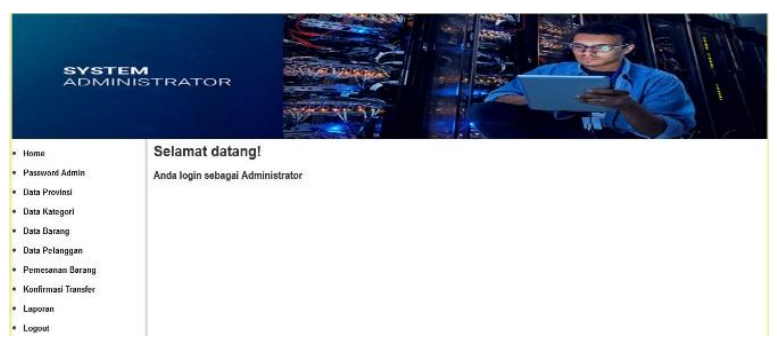

Figure 9. Main PageAdministrator

This section is the starting page where the admin enters the account to manage the content of the e-commerce website.

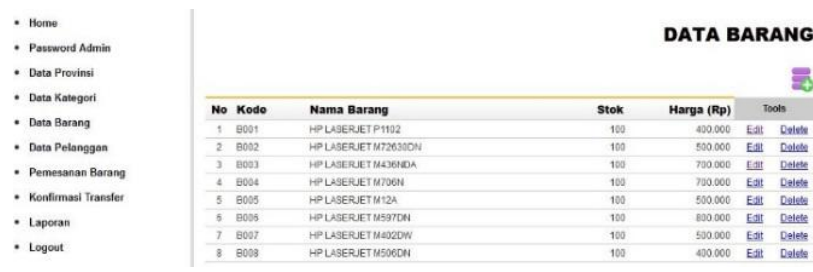

Figure 10. Inventory List

Figure 10 above is the place where the admin manages the list of items being sold, both deleting items, adding, changing goods and selling prices. 
Designing the application based on the data obtainedthrough questionnaires and processed with usability tests, the resulting ecommerce application or website is made to help solve the problems contained in the above framework. Especially in cases of harassment such as building an online media sales system that is centered and sources data from users.

\section{CONCLUSION}

After doing research and observation at PT. Multi Prima Mandiri Sukses, the following conclusions are:

1. With the existence of an online shopping system (e-commerce) with questionnaires distributed, the results are $81.4 \%$ that the system can help companies to marketing their products more widely.

2. In the results of the efficiency test, there are results of $74.2 \%$, that the system produces efficiency, that make system can be accessed easily by consumers anywhere and anytime.

In the application of the User Centered Deisgn method, with the Usability Test questionnaire, that the system can be easily learned with a value of $83.2 \%$, it becomes easy to remember by $79.2 \%$, and minimizes the difficulty by $60.8 \%$. By focusing on the needs and capabilities of users.

\section{REFERENCES}

[1] Yuliani, Ayu. 2019. Kominofo.go.id. 15 11. Diakses 08 24, 2020. https://kominfo.go.id/content/detail/11526/kemenkop-ukm-379-juta-umkm-sudah-goonline/0/sorotan_media.

[2] Statista. 2016. 01 01. Diakses 08 24, 2020. https://databoks.katadata.co.id/datapublish/2016/11/16/transaksi-e-commerceindonesia-naik-500-dalam-5-tahun.

[3] FK, Sibero Alexander. 2011. Kitab Suci Web Programing. Yogyakarta: MediaKom.

[4] S. Anisah, "Perancangan Sistem Informasi Registrasi Online Untuk Penerimaan Siswa Baru Berbasis Web Pada SMK Negeri 1 Kelapa Bangka Barat," Jurnal SISFOKOM, vol. 07, no. 2, pp. 174-179, 2018.

[5] Y. Kustiyahningsih, Definisi HTML Dan Konsep Dasar Web, Jakarta: Graha Ilmu, 2011.

[6] Tata, Sutabri. 2012. Analisis Sistem Infomasi. Yogyakarta: Andi.

[7] Zahara. 2013. Perancangan aplikasi E-commerce penjualan sparepart forkflit dengan metode ucd. Jakarta: Pelita Informatika Budi Darma.

[8] _ 2013. Perancangan aplikasi E-commerce penjualan sparepart forkflit dengan metode ucd. Jakarta: Pelita Informatika Budi Darma. 


\section{BIOGRAPHY}

Singgih Tanu Putra,A graduate from System Information Study Program (S1) of Buddhi Dharma University, 2020.

Edy,Achieved a Bachelor degree of Engineering at Gunadarma University in 2004. And obtained a Masters in Computer science from STMIK Eresha in 2012. He is currently a active lecturer of Software Engineering Study Program at Buddhi Dharma University. 